\title{
Expression and analyses of the HIF-1 pathway in the lungs of humans with pulmonary arterial hypertension
}

\author{
WEI LEI ${ }^{12^{*}}$, YUAN HE $^{1 *}$, XIAORONG SHUI ${ }^{3 *},{\text { GUOMING } \text { LI }^{2}, \text { GUOSEN YAN }}^{1,2}$, \\ YU ZHANG ${ }^{2}$, SHIAN HUANG ${ }^{2}$, CAN CHEN $^{1,2}$ and YUANLIN DING ${ }^{4}$ \\ ${ }^{1}$ Laboratory of Cardiovascular Diseases, Guangdong Medical University; ${ }^{2}$ Cardiovascular Medicine Center, \\ Affiliated Hospital of Guangdong Medical University; ${ }^{3}$ Laboratory of Vascular Surgery, Guangdong Medical University, \\ Zhanjiang, Guangdong 524000; ${ }^{4}$ Institute of Medical Systems Biology, Guangdong Medical University, \\ Dongguan, Guangdong 523808, P.R. China
}

Received August 2, 2015; Accepted July 22, 2016

DOI: $10.3892 / \mathrm{mmr} .2016 .5752$

\begin{abstract}
Pulmonary arterial hypertension (PAH) is characterized by endothelial dysfunction and structural remodeling of the pulmonary vasculature, mediated initially by reduced oxygen availability in the lungs. Hypoxia inducible factor (HIF), consisting of the functional subunit, HIF-1 $\alpha$, and the constitutively expressed HIF-1 $\beta$, is involved in the pathological processes associated with hypoxia. In the current study, the sequences of cDNAs and amino acids of HIF were characterized and analyzed using online bioinformatics tools. To further evaluate whether HIF accounts for the occurrence of $\mathrm{PAH}$, the present study determine the expression and phosphorylation levels of HIF and its associated pathways, including extracellular signal-regulated kinase (Erk)1/2 and phosphoinositide 3-kinase (PI3K)/Akt, in the lungs of patients with $\mathrm{PAH}$ by reverse transcription-quantitative polymerase chain reaction and western blotting. The mRNA expression levels of PI3K, Erk2, and HIF-1 $\alpha$ in the patients with PAH were significantly higher, compared with those in the control group, by 3.6-fold $(\mathrm{P}<0.01), 4.06$-fold and 2.64-fold $(\mathrm{P}<0.05)$, respectively. No significant differences were found in the mRNA and protein levels of Akt between the two groups $(\mathrm{P}>0.05)$. The protein levels of phosphorylated $(\mathrm{p}-)$ Akt, Erk1/2, p-Erk1/2, HIF-1 $\alpha$ and HIF-1 $\beta$ were significantly
\end{abstract}

Correspondence to: Dr Yuanlin Ding, Institute of Medical Systems Biology, Guangdong Medical University, 57 Xincheng Road, Dongguan, Guangdong 523808, P.R. China

E-mail: gdmcsbd@126.com

Dr Can Chen, Laboratory of Cardiovascular Diseases, Guangdong Medical University, 57 Renmin Road, Xiashan, Zhanjiang, Guangdong 524000, P.R. China

E-mail: chencan_21@126.com

*Contributed equally

Key words: pulmonary arterial hypertension, hypoxia inducible factor- $1 \alpha$, hypoxia inducible factor- $1 \beta$, signaling pathway, lung increased by 5.89-, 0.5-, 0.59-, 1.46- and 0.92-fold, respectively, in the patients with $\mathrm{PAH}$, compared with those in the controls group $(\mathrm{P}<0.01$ for $\mathrm{p}-\mathrm{Akt}$, Erk1/2; $\mathrm{P}<0.05$ for p-Erk1/2, HIF-1 $\alpha$ and HIF-1 $\beta$ ). These findings suggested that the mitogen-activated protein kinase and PI3K/Akt signaling pathways, and HIF-1 may perform a specific function in the pathogenesis of PAH.

\section{Introduction}

Pulmonary arterial hypertension (PAH), defined as a mean pulmonary arterial pressure (mPAP) $\geq 25 \mathrm{~mm} \mathrm{Hg}$ at rest, is a clinical syndrome of heart-lung circulation disorder, and can ultimately result in right heart failure with higher morbidity and mortality rates $(1,2)$. Various types of PAH may affect up to $100,000,000$ individuals worldwide (3). The estimated prevalence of PAH is $\sim 15 / 1,000,000$ individuals, with a mean age of $50 \pm 15$ years, and women constitute $75 \%$ of those diagnosed $(4,5)$. The average duration between the onset of symptoms and diagnosis is $>2$ years (5), and the 5-year mortality rate has reached $34 \%$ (6), reinforcing the importance of diagnosis, treatment and prognosis of PAH, which depends on investigations of the pathogenesis and etiology of the disease.

PHA is characterized by endothelial dysfunction and structural remodeling of the pulmonary vasculature, mediated initially by reduced oxygen availability in the lungs $(7,8)$. Cell sensing and rapid response to oxygen deprivation are essential for survival of the organisms, in which the regulation of oxygen homeostasis becomes an important physiological system (9). As a result of evolution, adaptation to hypoxia involves a number of genes, in which hypoxia inducible factor (HIF) is considered to be a core regulator (10).

The first HIF, HIF-1, is a highly conserved transcription factor in almost all cells, and is involved in pathological processes associated with hypoxia, including pulmonary and systemic hypertension, cancer and ischemic myocardial injury (11-14). HIF-1 is a heterodimeric protein comprised of an oxygen-regulated HIF-1 $\alpha$ subunit and a constitutively expressed HIF-1 $\beta$ subunit, also termed aryl hydrocarbon receptor nuclear translocater $(15,16)$. HIF-1 $\alpha$ is a master 
regulator of transcription in hypoxic cells and forms a dimer with HIF-1 $\beta$, further activating genes involved in energy metabolism, cell proliferation and extracellular matrix reorganization $(17,18)$. It has been reported that hypoxia mediates vascular remodeling through the induction of HIF-1 $\alpha$. In particular, HIF-1 $\alpha$ in smooth muscle cells was demonstrated to be important in hypoxia-induced PAH in mice (19-21). However, the upstream signaling events responsible for hypoxia, and its effects on the proliferation of vascular smooth muscular and endothelial cells, remain to be fully elucidated.

Certain reports have shown that the expression and activity of HIF-1 $\alpha$ are regulated by several protein kinase signaling pathways, in which extracellular signal-regulated kinase (ERK) and the serine/threonine kinase, Akt, have been identified as potent modulators of the expression of HIF-1 $\alpha$ (22-25). ERK is a subfamily member of the mitogen-activated protein kinase (MAPK) family, and its pathway has been recognized to mediate cell growth, proliferation and survival $(26,27)$. Li et al (28) found that the activation of ERK signaling induces the expression of HIF-1 $\alpha$ and stimulates its transcriptional activity in the developing rat brain following hypoxia-ischemia, and an increase in the phosphorylation of ERK1/2 has been observed in retinal neovascularization and vein occlusion (29). In addition, Akt is activated by the phosphoinositide 3-kinase (PI3K)-dependent pathway, which is crucial in cell differentiation, proliferation and survival $(30,31)$. Numerous studies have revealed the PI3K/Akt pathway to be critical for ischemia and angiogenesis $(32,33)$, for example, the PI3K/Akt pathway is required for the upregulation of HIF-1 $\alpha$ in a rat model of focal cerebral ischemia $(34,35)$. However, whether these two pathways account for the occurrence of PAH induced by hypoxic conditions remains to be elucidated.

In the present study, the genes coding HIF-1 $\alpha$ proteins were cloned from the lung tissues of human patients with $\mathrm{PAH}$, and then were investigated by immunofluorescent techniques and bioinformatic methods. In addition, the expression and phosphorylation levels of the HIF-1 $\alpha$ pathway components, including PI3K, Akt, ERK1/2 and HIF-1 $\beta$, were examined using reverse transcription-quantitative polymerase chain reaction (RT-qPCR) and western blot analyses, and the association between target genes and the development of PAH were examined. The present clinical study aimed to contribute to the elucidation of the role of HIF-1 $\alpha$ and its intracellular pathway in the occurrence of $\mathrm{PAH}$, and provide a reference for further functional investigations of the pathogenesis of PAH.

\section{Materials and methods}

Collection of clinical samples. Human lung tissues were collected from participants during palliative surgery at the Affiliated Hospital of Guangdong Medical College (Guangdong, China). The participants comprised patients with PAH (mPAP >30 mmHg; $n=5)$ and a control group of individuals with mPAP $\leq 20 \mathrm{mmHg}(\mathrm{n}=4)$. A total of 9 patients including 4 male and 5 female patients aged 15-53 years old (mean, 33.1 \pm 15.9 years old) were recruited. According to the updated clinical classification of pulmonary hypertension, and the guidelines of the American College of Cardiology and American Heart Association, PAH was diagnosed using right heart catheterization (36). The lung tissues collected from the inferior lobes of left lungs were stored at $-80^{\circ} \mathrm{C}$ for further manipulation. All clinical protocols and experimental procedures were approved by the ethics committee of the Affiliated Hospital of Guangdong Medical College, and a written informed consent form was obtained from each individual participant.

Gene cloning. The cDNA fragments of HIF-1 $\alpha$ and HIF-1 $\beta$ of patients with PAH were amplified using the Takara RNA LA PCR kit (AMV). PCR amplification was conducted at $94^{\circ} \mathrm{C}$ for $4 \mathrm{~min}$, followed by 35 cycles at $94^{\circ} \mathrm{C}$ for $40 \mathrm{~s}$, at $60^{\circ} \mathrm{C}$ for $50 \mathrm{~s}$, at $72^{\circ} \mathrm{C}$ for $3 \mathrm{~min}$, and a final extension at $72^{\circ} \mathrm{C}$ for $10 \mathrm{~min}$. The primer sequences of human HIF- $1 \alpha$ were 5'-CGAACGACAAGAAAAAGATAAG-3' (sense) and 5'-CCACAGAAGATGTTTATTTGATG-3' (antisense), and HIF-1 $\beta$ were 5'-CCGAAATGACATCAGATGTAC-3' (sense) and 5'-GTTAGATCAGGGAATTCTTCATTG-3' (antisense). The PCR products were sequenced by Invitrogen (Thermo Fisher Scientific, Inc., Shanghai, China). The sequencing results were used as queries in the BLAST searches (http:// blast.ncbi.nlm.nih.gov/Blast.cgi).

Bioinformatic analyses. The sequences containing the complete coding regions of the human HIF-1 $\alpha$ and HIF-1 $\beta$ genes, and the corresponding amino acid sequences were obtained from the GenBank (http://www.ncbi.nlm.nih. gov/genbank) and GenPept (http://www.ncbi.nlm.nih.gov/ protein) databases (HIF-1 $\alpha$, GenBank accession no. U22431; GenPept accession no. AAC50152; HIF-1 $\beta$, GenBank accession no. M69238; GenPept accession no. AAH60838 (37,38).

Comparative bioinformatics analyses of HIF-1 $\alpha$ and HIF-1 $\beta$ were performed online (http://www.ncbi.nlm.nih. gov and http://www.expasy.org). The protein physical and chemical parameters were circulated using the Protparam tool (http://web.expasy.org/protparam) (39). The motifs and structural domains were searched in the amino acid sequences using the NCBI conserved domain database (CDD; http:// www.ncbi.nlm.nih.gov/Structure/cdd/cdd.shtml) (40-43) and the secondary structures were predicted using the self-optimized prediction method (SOPMA; https://npsa-prabi.ibcp. fr/cgi-bin/npsa_automat.pl?page=npsa_sopma.html) (44).

$R T$-qPCR analysis. The lung tissues were homogenized on ice with a Teflon-pestle homogenizer in TRIzol reagent (Invitrogen; Thermo Fisher Scientific, Inc., Waltham, MA, USA), and total RNAs were isolated following the manufacturer's instructions. A $1 \mu \mathrm{g}$ sample of total RNA was reverse-transcribed into cDNA using AMV Reverse Transcriptase XL (Takara Bio, Inc., Otsu, Japan) and olido (dT) primers at $42^{\circ} \mathrm{C}$ for $1 \mathrm{~h}$. The primers for RT-qPCR are listed in Table I; GAPDH was selected as the internal control gene for normalization. The qPCR analysis was performed using $2 \mu \mathrm{l}$ of cDNA in a total volume of $20 \mu \mathrm{l}$ containing $10 \mu \mathrm{l} 2 \mathrm{X}$ SYBR Premix Ex Taq II (Takara Bio, Inc.), $0.8 \mu \mathrm{l}$ forward primer $(10 \mu \mathrm{M})$ and $0.8 \mu \mathrm{l}$ reverse primer $(10 \mu \mathrm{M})$, in a LightCycler ${ }^{\circledR} 480$ System Real-Time PCR system (Roche Diagnostics GmbH, Mannheim, Germany) using the following thermal cycling profile: $95^{\circ} \mathrm{C}$ for $30 \mathrm{sec}$, followed by 
Table I. Sequences of primers.

\begin{tabular}{ll}
\hline Gene & \multicolumn{1}{c}{ Primer sequence } \\
\hline GAPDH & Forward 5'-GGCACAGTCAAGGCTGAGAATG-3' $(\mathrm{bp})$ \\
& Reward 5'-ATGGTGGTGAAGACGCCAGTA-3' \\
PIK3CA & Forward 5'-TCTGTCTCCTCTAAACCCTG-3 \\
& Reward 5'-TTCTCCCAATTCAACCAC-3' \\
Akt1 & Forward 5'-TCTTTGCCGGTATCGTGT-3' \\
& Reward 5'-TGTCATCTTGGTCAGGTGGT-3' \\
Erk1 & Forward 5'-GGGGAGGTGGAGATGGTGA-3' \\
& Reward 5'-GCTGGCAGTAGGTCTGATGTT-3' \\
Erk2 & Forward 5'-TGTTCCCAAATGCTGACT-3' \\
& Reward 5'-AACTTGAATGGTGCTTCG-3' \\
HIF-1 $\alpha$ & Forward 5'-GCTCATCAGTTGCCACTTCCAC-3 \\
& Reward 5'-CATCTGTGCTTTCATGTCATCTTC-3' \\
HIF-1 $\beta$ & Forward 5'-TGTGGACCCAGTTTCTGTGA-3 \\
& Reward 5'-GACCACCACGAAGTGAGGTT-3' \\
& \\
&
\end{tabular}

PIK3CA, phosphatidylinositol- 3-kinase catalytic subunit $\alpha$; Erk, exrtracellular signal-regulated kinase; HIF, hypoxia inducible factor.

40 cycles of amplification $\left(95^{\circ} \mathrm{C}\right.$ for $5 \mathrm{sec}$ and $60^{\circ} \mathrm{C}$ for $\left.20 \mathrm{sec}\right)$. The qPCR reactions were performed in triplicate. Fluorescence was detected during annealing and extension, and melting curve analysis was performed immediately following the PCR cycling. The relative transcript levels were analyzed using the $2^{-\Delta \Delta \mathrm{Cq}}$ method (45).

Western blot analysis. The lung tissues were homogenized in ice-cold cell lysis buffer for western blot analysis and IP (Beyotime Institute of Biotechnology, Shanghai, China), and were centrifuged at $10,000 \times \mathrm{g}$ for $5 \mathrm{~min}$ at $4^{\circ} \mathrm{C}$. The supernatants were used for sodium dodecyl sulfate-polyacrylamide gel electrophoresis (SDS-PAGE) and western blot analysis. The concentrations of the proteins in the supernatants were detected using an Enhanced BCA Protein Assay kit (Beyotime Institute of Biotechnology). The protein $(\sim 50 \mu \mathrm{g})$ was separated using $10 \%$ SDS-PAGE and transferred onto PVDF membranes (EMD Millipore, Billerica, MA, USA). The membranes were blocked with $5 \%$ fat-free milk in Tris-buffered saline with $0.1 \%$ Tween-20 (TBS-T) and probed with the following primary antibodies: Mouse monoclonal HIF-1 $\alpha$ (610958; 1:500; BD Biosciences, San Jose, CA, USA), rabbit polyclonal HIF-1 $\beta$ (bs-1407R; 1:500, BIOSS, Beijing, China), rabbit monoclonal ERK (\#4695; 1:1,000; Cell Signaling Technology,Inc., Danvers, MA, USA), rabbit monoclonal phosphorylated (p)-ERK (Thr202/Tyr204; \#4370; 1:2,000; Cell Signaling Technology, Inc.), rabbit monoclonal Akt (\#4691; 1:1,000; Cell Signaling Technology, Inc.) and p-Akt (ser473; \#4060; 1:2,000; Cell Signaling Technology, Inc.) in TBS-T containing 5\% bovine serum albumin (Beyotime Institute of Biotechnology) overnight at $4^{\circ} \mathrm{C}$. Following rinsing in TBS-T three times, the membranes were incubated with goat anti-mouse (\#7076) and goat anti-rabbit (\#7074) horseradish-peroxidase-coupled secondary antibodies (Cell Signaling Technology, Inc.) for $1 \mathrm{~h}$ at room temperature. Immunodetection was performed using
BeyoECL Plus (Beyotime Institute of Biotechnology). Bands were visualized using the Bio-Rad ChemiDoc MP system (Bio-Rad Laboratories, Inc., Hercules, CA, USA) and analyzed using Quantity One software (Bio-Rad Laboratories, Inc.).

Statistical analysis. Data were analyzed using an independent-samples $t$-test with SPSS 20.0 software (IBM SPSS, Armonk, NY, USA. The data are presented as the mean \pm standard deviation. $\mathrm{P}<0.05$ was considered to indicate a statistically significant difference.

\section{Results}

Bioinformatics analysis of $H I F-1 \alpha$ and $H I F-1 \beta$. The cDNA sequences of human HIF-1 $\alpha$ and HIF-1 $\beta$ were aligned using the Basic Local Alignment Search Tool (BLAST) in the nucleotide database, and the results showed that they were $100 \%$ homologous with homo sapiens HIF-1 $\alpha$ and HIF-1 $\beta$ mRNAs, respectively. The biochemical properties and molecular structures of human HIF-1 $\alpha$ and HIF-1 $\beta$ were analyzed using the online tools, ProtParam and SOPMA, the results of which are listed in the Table II. As the dimer of these two subunits, the HIF protein was found to consist of 1,244 amino acids with a molecular weight of $138.592 \mathrm{Da}$; the most frequent residues were Leu and Ser. The functional domains were scanned in the CDD database (Fig. 1), following which three motifs were obtained, including a basic-helix-loop-helix (bHLH) region and two PAS repeat profiles, which have been previously demonstrated to be transcriptional activators of HIF-1 $\alpha$ and HIF-1 $\beta$ in mammals $(46,47)$.

Expression of the PI3K/Akt pathway. The relative mRNA expression level of PI3K was significantly elevated (2.6-fold) in the PAH group, compared with that in the control group $(\mathrm{P}<0.01$; Fig. 2). No significant differences in the mRNA or 
Table II. Biochemical properties and molecular structures of HIF-1 $\alpha$ and HIF-1 $\beta$.

\begin{tabular}{|c|c|c|}
\hline Index & HIF-1 $\alpha$ & HIF-1 $\beta$ \\
\hline Amino acids (n) & 826 & 416 \\
\hline Molecular weight (Da) & $92,670.4$ & $45,921.6$ \\
\hline Theoretical isoelectric point & 5.17 & 5.79 \\
\hline Formula & C4027H6410N1108O1309S43 & C1963H3146N584O637S25 \\
\hline Atoms (n) & 12,897 & 6,355 \\
\hline Extinction coefficients & 50,155 & 20,690 \\
\hline Estimated half-life (h) & 30 & 30 \\
\hline Instability index & 55.97 & 52.65 \\
\hline Aliphatic index & 74.96 & 71.44 \\
\hline Grand average hydropathicity & -0.573 & -0.508 \\
\hline Charged amino acids (\%) & 31.72 & 31.97 \\
\hline Acidic amino acids $(\%)$ & 14.29 & 13.46 \\
\hline Basic amino acids (\%) & 10.29 & 11.78 \\
\hline Polar amino acids (\%) & 31.60 & 29.09 \\
\hline Hydrophobic amino acids (\%) & 27.60 & 28.13 \\
\hline \multicolumn{3}{|l|}{ Major amino acids (\%) } \\
\hline & Leu 10.05 & Ser 9.86 \\
\hline & Ser 9.44 & Leu 7.69 \\
\hline & Thr 7.99 & Asp 7.69 \\
\hline \multicolumn{3}{|l|}{ Secondary structure (\%) } \\
\hline$\alpha$-helix & 30.87 & 30.29 \\
\hline Extended strand & 18.28 & 19.71 \\
\hline Random coil & 43.83 & 41.11 \\
\hline
\end{tabular}

HIF, hypoxia inducible factor.

protein levels of Akt were found between the two groups $(\mathrm{P}>0.05)$, however, the level of $\mathrm{p}$-Akt in the PAH group was significantly increased (5.89-fold), compared with that in the control group, indicating that Akt was activated though phosphorylation by PI3K ( $\mathrm{P}<0.01$; Figs. 2 and 3$)$.

Expression of the Erk1/2 pathway. The mRNA level of Erk2 in the PAH group was 3.06-fold higher, compared with that of control group $(\mathrm{P}<0.05)$, however, no significant difference in the mRNA level of Erk1 was observed between the two groups ( $\mathrm{P}>0.05$; Fig. 2). The results of the western blot analysis showed that the protein levels of Erk1/2 and p-Erk1/2 in the PAH group were significantly upregulated, compared with those in the control group $(\mathrm{P}<0.01$ and $\mathrm{P}<0.05$, respectively; Fig. 3).

Expression levels of $H I F-1 \alpha$ and $H I F-1 \beta$. The mRNA and protein levels of HIF-1 $\alpha$ in the PAH group were respectively increased by 1.64- and 1.46-fold, compared with the control group $(\mathrm{P}<0.01$ and $\mathrm{P}<0.05$, respectively), suggesting that a higher mRNA level of HIF-1 $\alpha$ increased synthesis of the HIF-1 $\alpha$ protein (Figs. 2 and 3). No significant difference in the mRNA level of HIF-1 $\beta$ was found between the two groups, however, the protein level of HIF-1 $\beta$ was significantly elevated (by $92 \%$ ) in the PAH group, compared with that in the control group ( $\mathrm{P}<0.05$; Figs. 2 and 3$)$.

\section{Discussion}

Pulmonary vascular remodeling, including hyperplasia of pulmonary artery endothelial cells and pulmonary artery smooth muscle cells is the major pathological change in $\mathrm{PAH}$. Multiple cytokines, including platelet-derived growth factor, vascular endothelial growth factor and transforming growth factor- $\beta$ can promote cell proliferation and migration in the physiopathological processes of PAH (48-50).

The MAPK family comprises key factors for regulating the proliferation, differentiation and apoptosis of cells in response to certain environmental stresses and cytokines $(51,52)$. MAPKs usually exist in forms of non-phosphorylated proteins in mammalian cells. As a member of the MAPK family, Erk1/2 can be activated though phosphorylation of the Thr185 and Tyr187 residues to produce a dimer, which is then translocated into the cell nucleus to activate various transcription factors (53). In the present study, it was found that Erk1/2 and p-Erk1/2 were upregulated in the patients with PAH, suggesting that Erk1/2 signaling pathway may be important for pulmonary vascular remodeling in $\mathrm{PAH}$.

Similar to the MAPK signaling pathway, PI3K/Akt also induces cell growth, triggered by certain growth factors (54). Activated PI3K drives the production of 


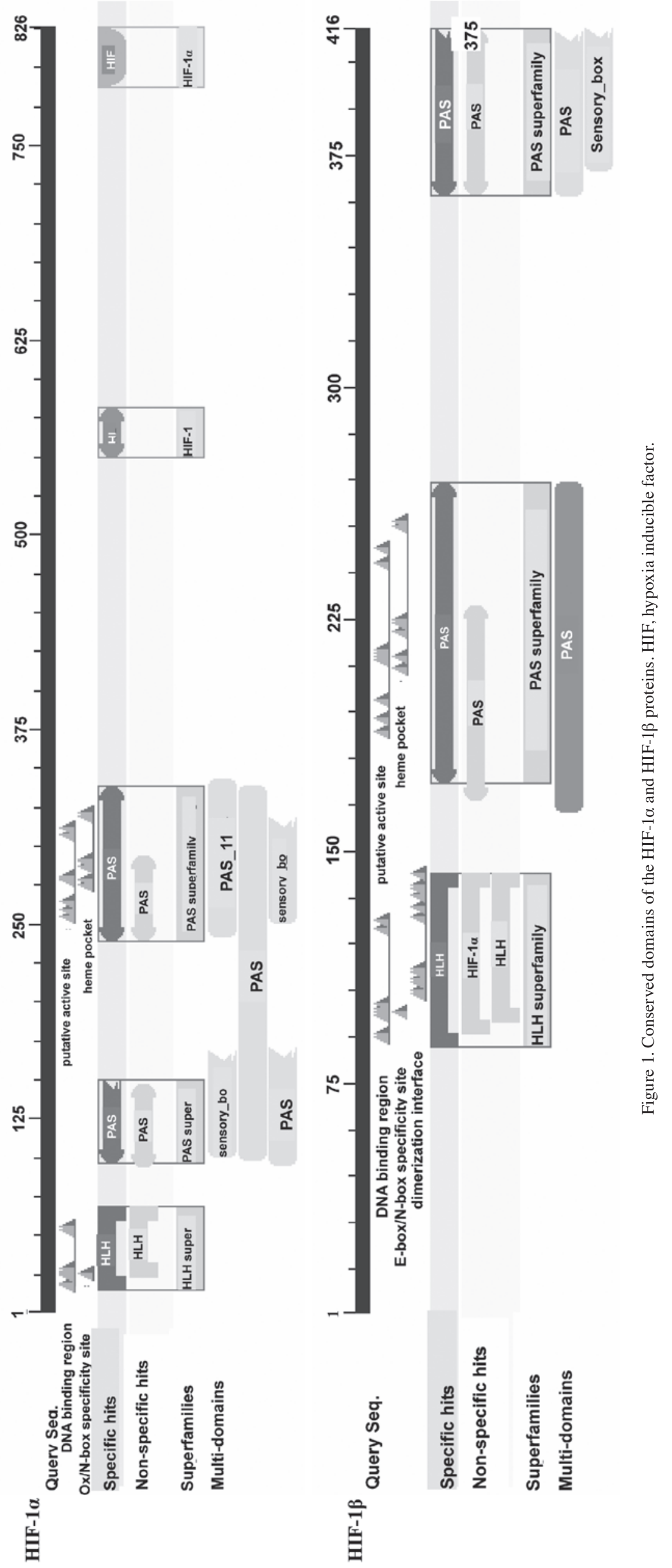




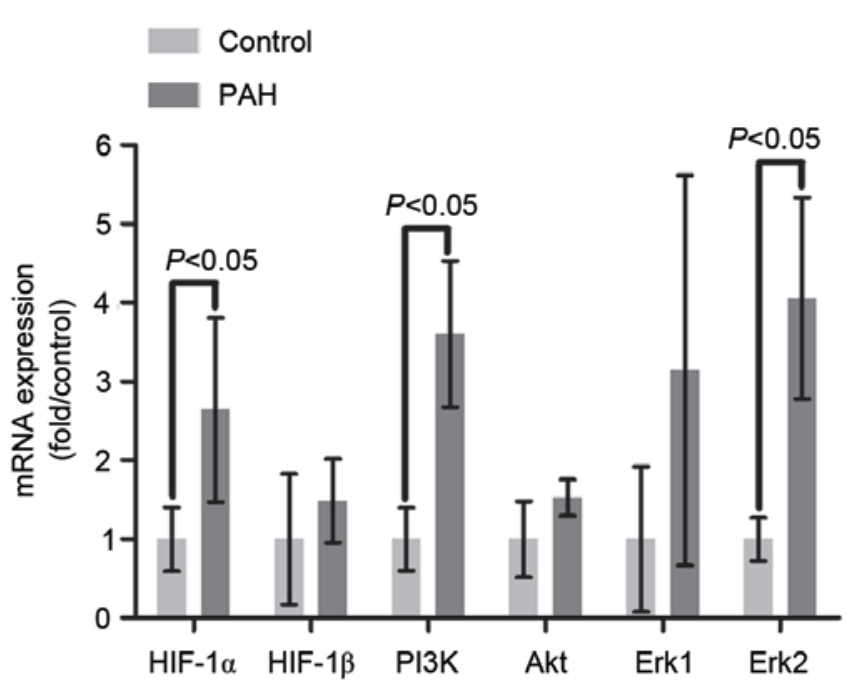

Figure 2. mRNA expression levels of HIF-1 $\alpha$, HIF-1 $\beta$, PI3K, Akt, Erk1 and Erk2 in patients with PAH and control individuals. GAPDH was used as an internal control. Fold changes in the expression, compared with the control were calculated using the $2^{-\Delta \Delta \mathrm{Cq}}$ method. Data are expressed as the mean \pm standard deviation. PAH, pulmonary arterial hypertension; HIF, hypoxia inducible factor; PI3K, phosphoinositide 3-kinase; Erk, extracellular signal-regulated kinase.

phosphatidyl-inositol-3,4,5-trisphosphate, which can bind to pleckstrin homology domains of Akt, and promote Akt phosphorylation at Thr308 and Ser473 residues, which induces the translocation of Akt into the nucleus to provide signals for cell survival (55). In addition, the second messenger PIP3 interacts with several cytoskeletal proteins, including paxilin, profilin, vinculin and filamin, to promote the polymerization of actin filaments, which can affect cell morphosis and migration (56-59). The present study showed that the levels of PI3K and phosphorylated Akt were markedly elevated in the patients with PAH, suggesting that the PI3K/Akt pathway may be involved in the pathological lesion of PAH by regulating cell proliferation, migration and adhesion, and even vascular stability.

HIF- $1 \alpha$ and HIF-1 $\beta$ belong to the bHLH/PAS protein family, functioning as modulators in cell proliferation and differentiation (60). As HIF-1 $\alpha$ lacks a transmembrane domain, HIF-1 $\beta$ is recruited to dimerize with HIF- $1 \alpha$ for nuclear translocation. The degradation of the HIF-1 $\alpha$ is suppressed by hypoxia, whereas the expression of HIF-1 $\beta$ in cells is commonly considered to be oxygen-independent. However, Wolff et al (61) found that the regulation of HIF-1 $\beta$ is more complex, and showed that the protein levels of HIF-1 $\beta$ are affected by hypoxia and hypoxia mimetics (61). In addition to HIF-1 $\alpha$, the present study found that the protein levels of HIF-1 $\beta$ were also elevated in the lungs of patients with PAH, suggesting that these two molecules may be involved in the pathogenesis of PAH. Therefore, the present study hypothesized that HIF-1 $\beta$ may exhibit corresponding responses to the changes of HIF-1 $\alpha$.

The present study demonstrated for the first time, to the best of our knowledge, changes in the expression levels of ERK1/2, PI3K, Akt and HIF-1 in the lungs of patients with
A

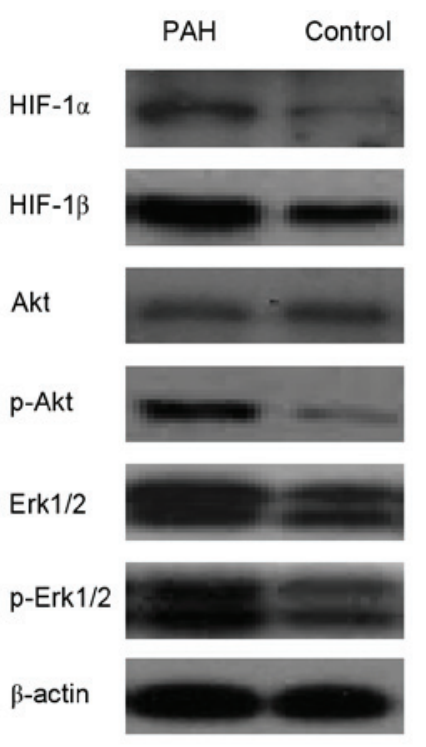

B

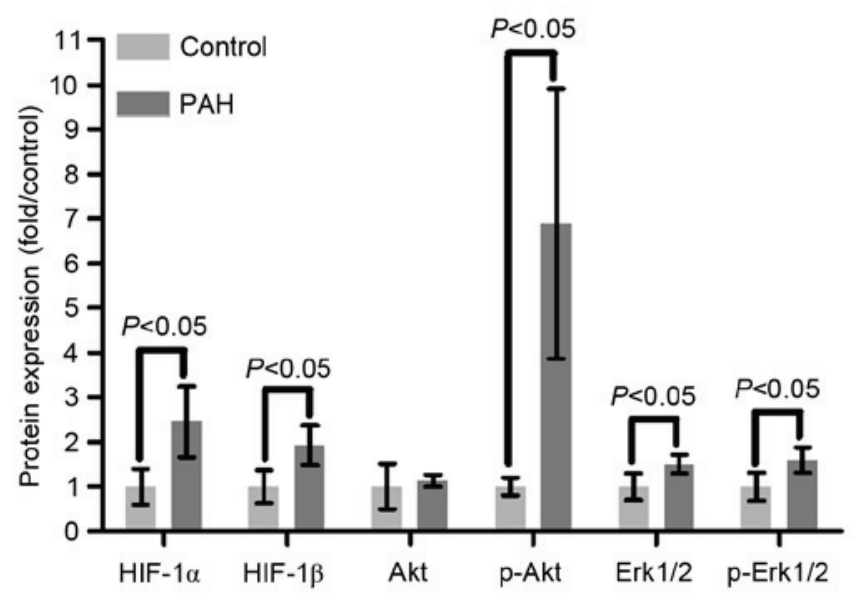

Figure 3. (A) Representative images of western blot analysis. (B) Relative protein levels of HIF-1 $\alpha$, HIF-1 $\beta$, Akt, p-Akt, Erk $1 / 2$ and p-Erk1/2 in the patients with $\mathrm{PAH}$ and the control individuals were determined using wetern blot analysis. $\beta$-actin was used as an internal control. Values are expressed as the mean fold change \pm standard deviation relative to the control. PAH, pulmonary arterial hypertension; HIF, hypoxia inducible factor; PI3K phosphoinositide 3-kinase; Erk, extracellular signal-regulated kinase; p-phosphorylated.

PAH. However, the roles of these signaling molecules in the pathogenesis of PAH and the associations among these signaling molecules require further investigations in the future.

\section{Acknowledgements}

This study was supported by Collaborative Innovation and Platform Environment Construction Projects of Guangdong Province (2015A050502049), Natural Science Foundation of Guangdong Province (2015A030313520), Science and Technology Planning Project of Guangdong Province (2014A020212739), Research Project of Traditional Chinese 
Medicine Bureau of Guangdong Province (20151259, 20161142) and the National Natural Science Foundation of China (no. 81300035).

\section{References}

1. Stamm JA, Risbano MG and Mathier MA: Overview of current therapeutic approaches for pulmonary hypertension. Pulm Circ 1: 138-159, 2011.

2. Savai R, Al-Tamari HM, Sedding D, Kojonazarov B, Muecke C, Teske R, Capecchi MR, Weissmann N, Grimminger F, Seeger W, et al: Pro-proliferative and inflammatory signaling converge on FoxO1 transcription factor in pulmonary hypertension. Nat Med 20: 1289-1300, 2014.

3. Seeger W and Pullamsetti SS: Mechanics and mechanisms of pulmonary hypertension-Conference summary and translational perspectives. Pulm Circ 3: 128-136, 2013.

4. Humbert M, Sitbon O, Chaouat A, Bertocchi M, Habib G, Gressin V, Yaici A, Weitzenblum E, Cordier JF, Chabot F, et al: Pulmonary arterial hypertension in France: Results from a national registry. Am J Respir Crit Care Med 173: 1023-1030, 2006.

5. Badesch DB, Raskob GE, Elliott CG, Krichman AM, Farber HW, Frost AE, Barst RJ, Benza RL, Liou TG, Turner M, et al: Pulmonary arterial hypertension: Baseline characteristics from the REVEAL Registry. Chest 137: 376-387, 2010.

6. Thenappan T, Shah SJ, Rich S, Tian L, Archer SL and Gomberg-Maitland M. Survival in pulmonary arterial hypertension: A reappraisal of the NIH risk stratification equation. Eur Respir J 35: 1079-1087, 2010.

7. McCullagh BN, Costello CM, Li L, O'Connell C, Codd M, Lawrie A, Morton A, Kiely DG, Condliffe R, Elliot C, et al: Elevated plasma CXCL1 $2 \alpha$ is associated with a poorer prognosis in pulmonary arterial hypertension. PLoS One 10: e0123709, 2015.

8. Huang X, Zou L, Yu X, Chen M, Guo R, Cai H, Yao D, $\mathrm{Xu} \mathrm{X}$, Chen Y, Ding C, et al: Salidroside attenuates chronic hypoxia-induced pulmonary hypertension via adenosine A2a receptor related mitochondria-dependent apoptosis pathway. J Mol Cell Cardiol 82: 153-166, 2015.

9. Shimoda LA and Laurie SS: HIF and pulmonary vascular responses to hypoxia. J Appl Physiol (1985) 116: 867-874, 2014.

10. Prabhakar NR and Semenza GL: Adaptive and maladaptive cardiorespiratory responses to continuous and intermittent hypoxia mediated by hypoxia-inducible factors 1 and 2 . Physio Rev 92: 967-1003, 2012

11. Cai Z, Luo W, Zhan H and Semenza GL: Hypoxia-inducible factor 1 is required for remote ischemic preconditioning of the heart. Proc Natl Acad Sci USA 110: 17462-17467, 2013.

12. Gilkes DM, Xiang L, Lee SJ, Chaturvedi P, Hubbi ME, Wirtz D and Semenza GL: Hypoxia-inducible factors mediate coordinated RhoA-ROCK1 expression and signaling in breast cancer cells. Proc Natl Acad Sci USA 111: E384-E393, 2014

13. Huang S, Chen P, Shui X, He Y, Wang H, Zheng J, Zhang L, Li J, Xue Y, Chen C and Lei W: Baicalin attenuates transforming growth factor- $\beta 1$-induced human pulmonary artery smooth muscle cell proliferation and phenotypic switch by inhibiting hypoxia inducible factor- $1 \alpha$ and aryl hydrocarbon receptor expression. J Pharm Pharmacol 66: 1469-1477, 2014.

14. Semenza GL: Regulation of oxygen homeostasis by hypoxia-inducible factor 1. Physiology (Bethesda) 24: 97-106, 2009.

15. Sutton KM, Hayat S, Chau NM, Cook S, Pouyssegur J, Ahmed A, Perusinghe N, Le Floch R, Yang J and Ashcroft M: Selective inhibition of MEK1/2 reveals a differential requirement for ERK1/2 signalling in the regulation of HIF-1 in response to hypoxia and IGF-1. Oncogene 26: 3920-3929, 2007.

16. Xue Y, Li NL, Yang JY, Chen Y, Yang LL and Liu WC. Phosphatidylinositol 3'-kinase signaling pathway is essential for Racl-induced hypoxia-inducible factor-1 (alpha) and vascular endothelial growth factor expression. Am J Physiol Heart Circ Physiol 300: H2169-H2176, 2011.

17. Semenza GL: Hypoxia-inducible factors in physiology and medicine. Cell 148: 399-408, 2012.

18. Lim CS, Kiriakidis S, Sandison A, Paleolog EM and Davies AH: Hypoxia-inducible factor pathway and diseases of the vascular wall. J Vasc Surg 58: 219-230, 2013.
19. Kim YM, Barnes EA, Alvira CM, Ying L, Reddy S and Cornfield DN: Hypoxia-inducible factor- $1 \alpha$ in pulmonary artery smooth muscle cells lowers vascular tone by decreasing myosin light chain phosphorylation. Circ Res 112: 1230-1233, 2013.

20. Ball MK, Waypa GB, Mungai PT, Nielsen JM, Czech L, Dudley VJ, Beussink L, Dettman RW, Berkelhamer SK, Steinhorn RH, et al: Regulation of hypoxia-induced pulmonary hypertension by vascular smooth muscle hypoxia-inducible factor-1 $\alpha$. Am J Respir Crit Care Med 189: 314-324, 2014

21. Smith KA and Yuan JX: Hypoxia-inducible factor-1 $\alpha$ in pulmonary arterial smooth muscle cells and hypoxia-induced pulmonary hypertension. Am J Respir Crit Care Med 189: 245-246, 2014

22. Mottet D, Michel G, Renard P, Ninane N, Raes M and Michiels C: ERK and calcium in activation of HIF-1. Ann N Y Acad Sci 973: 448-453, 2002.

23. Lim JH, Lee ES, You HJ, Lee JW, Park JW and Chun YS: Ras-dependent induction of HIF-1alpha785 via the Raf/MEK/ERK pathway: A novel mechanism of Ras-mediated tumor promotion. Oncogene 23: 9427-9431, 2004.

24. Yuan L, Santi M, Rushing EJ, Cornelison R and MacDonald TJ: ERK activation of p21 activated kinase-1 (Pak1) is critical for medulloblastoma cell migration. Clin Exp Metastasis 27: 481-491, 2010.

25. Zhang L, Liu Q, Lu L, Zhao X, Gao X and Wang Y: Astragaloside IV stimulates angiogenesis and increases hypoxia-inducible factor-1 $\alpha$ accumulation via phosphatidylinositol 3-kinase/Akt pathway. J Pharmacol Exp Ther 338: 485-491, 2011.

26. Yang XM, Wang YS, Zhang J, Li Y, Xu JF, Zhu J, Zhao W, Chu DK and Wiedemann P: Role of PI3K/Akt and MEK/ERK in mediating hypoxia-induced expression of HIF-1alpha and VEGF in laser-induced rat choroidal neovascularization. Invest Ophthalmol Vis Sci 50: 1873-1879, 2009.

27. Jin J, Yuan F, Shen MQ, Feng YF and He QL: Vascular endothelial growth factor regulates primate choroid-retinal endothelial cell proliferation and tube formation through PI3K/Akt and MEK/ERK dependent signaling. Mol Cell Biochem 381: 267-272, 2013

28. Li L, Xiong Y, Qu Y, Mao M, Mu W, Wang H and Mu D: The requirement of extracellular signal-related protein kinase pathway in the activation of hypoxia inducible factor 1 alpha in the developing rat brain after hypoxia-ischemia. Acta Neuropathol 115: 297-303, 2008.

29. Bullard LE, Qi X and Penn JS: Role for extracellular signal-responsive kinase-1 and -2 in retinal angiogenesis. Invest Ophthalmol Vis Sci 44: 1722-1731, 2003.

30. Coffer PJ, Jin J and Woodgett JR: Protein kinase B (c-Akt): A multifunctional mediator of phosphatidylinositol 3-kinase activation. Biochem J 335: 1-13, 1998.

31. Kandel ES and Hay N: The regulation and activities of the multifunctional serine/threonine kinase Akt/PKB. Exp Cell Res 253: 210-229, 1999.

32. Ackah E, Yu J, Zoellner S, Iwakiri Y, Skurk C, Shibata R, Ouchi N, Easton RM, Galasso G, Birnbaum MJ, et al: Akt1/protein kinase Balpha is critical for ischemic and VEGF-mediated angiogenesis. J Clin Invest 115: 2119-2127, 2005 .

33. Steinle JJ, Zamora DO, Rosenbaum JT and Granger HJ: Beta 3 -adrenergic receptors mediate choroidal endothelial cell invasion, proliferation, and cell elongation. Exp Eye Res 80: 83-91, 2005.

34. Ye Z, Guo Q, Xia P, Wang N, Wang E and Yuan Y: Sevoflurane postconditioning involves an up-regulation of HIF-1 $\alpha$ and HO-1 expression via PI3K/Akt pathway in a rat model of focal cerebral ischemia. Brain Res 1463: 63-74, 2012.

35. Jeong YJ, Cho HJ, Magae J, Lee IK, Park KG and Chang YC: Ascofuranone suppresses EGF-induced HIF-1 $\alpha$ protein synthesis by inhibition of the Akt/mTOR/p70S6K pathway in MDA-MB-231 breast cancer cells. Toxicol Appl Pharmacol 273: $542-550,2013$

36. Simonneau G, Robbins IM, Beghetti M, Channick RN, Delcroix M, Denton CP, Elliott CG, Gaine SP, Gladwin MT, Jing ZC, et al: Updated clinical classification of pulmonary hypertension. J Am Coll Cardiol 54 (1 Suppl): S43-S54, 2009.

37. Strausberg RL, Feingold EA, Grouse LH, Derge JG, Klausner RD, Collins FS, Wagner L, Shenmen CM, Schuler GD, Altschul SF, et al: Generation and initial analysis of more than 15,000 full-length human and mouse cDNA sequences. Proc Natl Acad Sci USA 99: 16899-16903, 2002 
38. Wang GL, Jiang BH, Rue EA and Semenza GL: Hypoxia-inducible factor 1 is a basic-helix-loop-helix-PAS heterodimer regulated by cellular O tension. Proc Natl Acad Sci USA 92: 5510-5514, 1995.

39. Combet C, Blanchet C, Geourjon C and Deléage G: NPS@: Network protein sequence analysis. Trends Biochem Sci 25 $147-150,2000$

40. Marchler-Bauer A and Bryant SH: CD-Search: Protein domain annotations on the fly. Nucleic Acids Res 32 (Web Server issue): W327-W331, 2004.

41. Marchler-Bauer A, Anderson JB, Chitsaz F, Derbyshire MK, DeWeese-Scott C, Fong JH, Geer LY, Geer RC, Gonzales NR, Gwadz M, et al: CDD: Specific functional annotation with the conserved domain database. Nucleic Acids Res 37 (Database issue): D205-D210, 2009

42. Marchler-Bauer A, Lu S, Anderson JB, Chitsaz F, Derbyshire MK, DeWeese-Scott C, Fong JH, Geer LY, Geer RC, Gonzales NR, et al: CDD: A conserved domain database for the functional annotation of proteins. Nucleic Acids Res 39 (Database issue): D225-D229, 2011.

43. Marchler-Bauer A, Derbyshire MK, Gonzales NR, Lu S, Chitsaz F, Geer LY, Geer RC, He J, Gwadz M, Hurwitz DI, et al: CDD: NCBI's conserved domain database. Nucleic Acids Res 43 (Database issue): D222-D226, 2015.

44. Gasteiger E, Hoogland C, Gattiker A, Duvaud S, Wilkins M, Appel R and Bairoch A: Protein identification and analysis tools on the ExPASy server. In: John MW (ed): The Proteomics Protocols Handbook. Humana Press, Totowa, NJ, pp571-607, 2005.

45. Livak, KJ, Schmittgen, TD. Analysis of relative gene expression data using real-time quantitative PCR and the 2(-Delta Delta C(T)) Method. Methods 25: 402-408, 2001.

46. Reyes H, Reisz-Porszasz S and Hankinson O: Identification of the Ah receptor nuclear translocator protein (Arnt) as a component of the DNA binding form of the Ah receptor. Science 256 1193-1195, 1992.

47. Zhou YD, Barnard M, Tian H, Li X, Ring HZ, Francke U, Shelton J, Richardson J, Russell DW and McKnight SL: Molecular characterization of two mammalian bHLH-PAS domain proteins selectively expressed in the central nervous system. Proc Natl Acad Sci USA 94: 713-718, 1997.

48. Zhao Y,Lv W, Piao H, Chu X and Wang H: Role of platelet-derived growth factor-BB (PDGF-BB) in human pulmonary artery smooth muscle cell proliferation. J Recept Signal Transduct Res 34: 254-260, 2014.
49. Voelkel NF and Gomez-Arroyo J: The role of vascular endothelial growth factor in pulmonary arterial hypertension. The angiogenesis paradox. Am J Respir Cell Mol Biol 51: 474-484, 2014.

50. Gore B, Izikki M, Mercier O, Dewachter L, Fadel E, Humbert M, Dartevelle P, Simonneau G, Naeije R, Lebrin F and Eddahibi S: Key role of the endothelial TGF- $\beta$ /ALK1/endoglin signaling pathway in humans and rodents pulmonary hypertension. PLoS One 9: e100310, 2014.

51. McKay MM and Morrison DK: Integrating signals from RTKs to ERK/MAPK. Oncogene 26: 3113-3121, 2007.

52. Raman M, Chen W and Cobb MH: Differential regulation and properties of MAPKs. Oncogene 26: 3100-3112, 2007.

53. Barsyte-Lovejoy D, Galanis A and Sharrocks AD: Specificity determinants in MAPK signaling to transcription factors. J Biol Chem 277: 9896-9903, 2002.

54. McMullen JR and Jzumo S: Role of insulin-like growth factor 1 (IGF-1)/phosphoinositide-3-kinase (PI3K) pathway mediating physiological cardiac hypertrophy. Novartis Found Symp 274: 90-111; discussion 111-117, 152-155, 272-276, 2006.

55. Zhang Y, Tseng CC, Tsai YL, Fu X, Schiff R and Lee AS: Cancer cells resistant to therapy promote cell surface relocalization of GRP78 which complexes with PI3K and enhances PI(3,4,5)P3 production. PLoS One 8: e80071, 2013.

56. Vanhaesebroeck B and Waterfield MD: Signaling by distinct classes of phosphoinositide 3-kinases. Exp Cell Res 253: 239-254, 1999.

57. Vanhaesebroeck B, Leevers SJ, Ahmadi K, Timms J, Katso R, Driscoll PC, Woscholski R, Parker PJ and Waterfield MD: Synthesis and function of 3-phosphorylated inositol lipids. Annu Rev Biochem 70: 535-602, 2001.

58. Roymans D and Slegers H: Phosphatidylinositol 3-kinases in tumor progression. Eur J Biochem 268: 487-498, 2001.

59. Greenwood JA, Theibert AB, Prestwich GD and Murphy-Ullrich JE: Restructuring of focal adhesion plaques by PI 3-kinase. Regulation by Ptdlns $(3,4,5)-p(3)$ binding to alpha-actinin. J Cell Biol 150: 627-642, 2000.

60. Kietzmann T, Samoylenko A, Roth U and Jungermann K: Hypoxia-inducible factor-1 and hypoxia response elements mediate the induction of plasminogen activator inhibitor-1 gene expression by insulin in primary rat hepatocytes. Blood 101: 907-914, 2003.

61. Wolff M, Jelkmann W, Dunst J and Depping R: The aryl hydrocarbon receptor nuclear translocator (ARNT/HIF-1 $\beta$ ) is influenced by hypoxia and hypoxia mimetics. Cell Physiol Biochem 32: 849-858, 2013. 